Bangladesh J. Bot. 44(2): 237-244, 2015 (June)

\title{
PHYSICAL AND CHEMICAL PARAMETERS AND TRACE METAL FLUX IN WATER, SOIL AND PLANT SAMPLES COLLECTED FROM INDUSTRIAL EFFLUENT AFFECTED AREAS IN AND AROUND DHAKA CITY
}

\author{
Kazi Kamrun Nahar and Sheikh Shamimul Alam* \\ Department of Botany, University of Dhaka, Dhaka-1000, Bangladesh
}

Key words: Physico-chemical parameter, Industrial effluents, Colocasia esculenta, Ipomoea aquatica

\begin{abstract}
Water and soil samples were collected from five different industrial areas around Dhaka city namely, (i) Powertex Fashion Ltd., Gazipur (Textile), (ii) Shetu Pesticide Ltd., Savar (Pesticide), (iii) Salma Leather Industry, Hazaribagh (Tannery), (iv) Monno Ceramic Industries, Nayarhat, Dhamrai, (Ceramic) and (v) ACME Laboratories Ltd., Tulivita, Dhamrai (Pharmaceutical) where selected for this study. Two plants species viz. Colocasia esculenta (L.) Schott and Ipomoea aquatica Forssk. commonly growing in the industrial effluent affected areas were selected to observe the rate of heavy metal uptake. Dissolved oxygen (DO) was found below the permissible limit in all the affected areas (lowest $0.88 \mathrm{mg} / \mathrm{l}$ in tannery waste affected areas) indicating high amount of organic wastage discharge from tannery. Eight trace metals viz. arsenic, cadmium, nickel, iron, zinc, chromium, copper and lead were analysed for water, soil and plant samples. Arsenic and cadmium exceeded the permissible limit in water sample collected from all affected areas. Tannery waste affected area was found to be the most vulnerable area in respect to arsenic and chromium contamination. On the other hand, the highest amount of arsenic was found in the soil sample collected from pesticide affected area. The rate of heavy metal uptake in Colocasia esculenta (L.) Schott is much higher than Ipomoea aquatica Forssk. More heavy metals were accumulated in edible portion than roots of the plants.
\end{abstract}

\section{Introduction}

Industrial effluents are one of the major sources for direct and often continuous input of pollutants/toxicants into aquatic ecosystems with long-term implications (Odeigah and Osanyipeju 1995, Chan et al. 2003, Lah et al. 2004, Smolders et al. 2004). As a result of continuous input of different pollutants, it lowers the quality of life in various aspects and affects health and life span (Grover and Kaur 1999). Rapid industrialization of Bangladesh for the last two decades resulted above 30,000 large and small industries which are destructing our riverine system by discharging their effluents (Rahman et al. 2001). Most of the industries and factories are present in and around Dhaka city (Islam et al. 2011). The industries are situated on the banks of the river Buriganga, Turag etc. or very close to the river system. Among the industries, textile, leather, paint, pesticides, pharmaceuticals laboratories are northworthy (DoE 1997). Unfortunately, these industries do not follow any biosafety guideline. Even they do not have recommended waste management system, discharging their effluents directly into the different water bodies around the metropolis.

Besides rivers and streams, industrial effluents are also discharging into low-lying lands, causing soil pollution (Rahman et al. 2001). Textile, paper pulp, food, fish, tannery and distillery industries are mainly discharging biodegradable organic wastes (Rahman et al. 2001). These wastes undergo aerobic (i.e., using oxygen) decomposition in the receiving water body (Lenore et al. 1998). As a result, the oxygen content of water goes down, endangering fish and other aquatic

*Author for correspondence: <ssalam81@yahoo.com>. 
species (Meybeck et al. 1996). On the other hand, non-biodegradable wastes are mainly discharged by the pesticide, chemical, ceramic and pharmaceutical industries (Rahman et al. 2001). Many of the persistent compounds contained in these effluents are toxic and can have a devastating effect on the environment (Chhatwal et al.1989). Industrial effluents have been found to increase heavy metal load in surrounding agricultural soils (Joardar et al. 2005). Among the heavy metals, arsenic, cadmium, chromium, lead, nickel etc. are directly health hazardous (Huq et al. 2006).

These metals are taken up by plants. Colocasia esculenta, Ipomoea aquatica, Oryza sativa etc. growing on these contaminated soil are able to uptake and accumulate the toxic substances, even faster than other aquatic organisms (Huq et al. 2000). Everyday a huge amount of plants such as Colocasia esculenta and Ipomoea aquatica are coming from the various affected areas to the local markets and being sold at cheap price. These two plants are popular and a number of people feeding on this plants without knowing the sources. In this way, the toxic substances are entering into the human food chain and increasing the level of different heavy metals (Ahmed and Reazuddin 2000, Huq et al. 2008).

Therefore, it is an urgent need to know the extent of contamination of soil, water and plant species in and around the affected areas.

\section{Materials and Methods}

Colocasia esculenta (L.) Schott and Ipomoea aquatica Forssk. grown in and around the affected areas were used as sample. Moreover, these two species were collected form a village Shibrampur, Comilla as control. These plant were grown in the Botanic garden, Department of Botany, University of Dhaka under similar environment.

Five different industries were selected in this study. Water, soil and both plant samples were collected from the following areas: (i) Textile: Powertex Fashion Limited, Kolomeshwar, Board bazar, Gazipur. (ii) Pesticide: Shetu Pesticide Limited, Samko Jadur Char, Hemayetpur, Savar. (iii) Tannery: Hazaribagh Tannery Industries, Salma Leather Corporation, 56, Sanaton area, Hazaribagh, Dhaka. (iv) Ceramic: Monno Ceramic Industries, Nayarhat, Dhamrai, Dhaka. (v) Pharmaceutical: Acme Laboratory Limited, Tulivita, Dhamrai, Dhaka.

Moreover, the Botanic garden, Department of Botany, University of Dhaka was considered as control area for this study.

Water samples were collected at each area with water sampler (Model: UWITEC A-3510) in the midstream at a depth of 1 to 2 meters to avoid the interference of the floating substances. The high-density 1 liter PVC bottles were used for sample collection. Each bottle was cleaned thoroughly by rinsing with dilute $\mathrm{HNO}_{3}$ followed by washing with distilled water.

Water $\mathrm{pH}$ was determined by glass electrode $\mathrm{pH}$ meter (Model: Jenway Instrument, $\mathrm{pH}$ meter 3305). The electrical conductivity (EC) of water samples was directly determined in the river/canal by EC meter (Model: HANNA HI-8633) in $\mu \mathrm{S} / \mathrm{cm}$. A rapid determination of total dissolved solid (TDS) of water samples was done in the field by TDS meter (Model: Mettler Toledo Ag, CH-8603). Dissolved Oxygen of water samples was determined in the field by DO meter (Model: Mettler-Toledo Ag, CH-8603).

The collected water samples were filtered and preserved with conc. $\mathrm{HNO}_{3}$. Trace elements As, $\mathrm{Cd}, \mathrm{Cr}, \mathrm{Ni}, \mathrm{Fe}, \mathrm{Cu}, \mathrm{Zn}$ and $\mathrm{Pb}$ in water of the sample area were analyzed by using Atomic Absorption Spectroscopy (Model: Shimadzer-AA7000).

The soil samples of five affected areas were collected from five different locations on a composite soil sampling basis as suggested by Huq and Alam (2005). The samples were air dried 
and sieved through a $2.0 \mathrm{~mm}$ sieve, than mixed thoroughly and stored. A portion of the sample was ground and sieved through a $0.5 \mathrm{~mm}$ sieve for analysis.

The roots of both the plants species were washed with deionized distilled water for several times to remove the soil and ions adhering to root. The aerial parts of plants were also washed. The collected plant samples were first air-dried and then oven dried at $70 \pm 5^{\circ} \mathrm{C}$ for $48 \mathrm{hrs}$. The dry weights of plant samples were measured. The dry plant samples were then grinded and passed through a $0.2 \mathrm{~mm}$ sieve for analysis. Approximately $0.5 \mathrm{gm}$ (where available) of each plant sample was placed in a beaker with $15 \mathrm{ml}$ high-purity $\mathrm{HNO}_{3}-\mathrm{HClO}_{4}$ (3:1) acid mixture and allowed to stand at room temperature for overnight. These were then heated to $140-180^{\circ} \mathrm{C}$ for complete digestion. Plant samples were analyzed for total arsenic by hydride generated atomic absorption spectrometry (HG - AAS), while lead and cadmium were analyzed by AAS. At least five readings were taken for each experiment and the average values not ed.

The above mentioned chemical analysis were carried in Soil and Environmental Laboratory, BCSIR, Dhaka.

\section{Results and Discussion}

Four different physical and chemical parameters such as, hydrogen ion concentration $(\mathrm{pH})$, electrical conductivity (EC), dissolved oxygen (DO) and total dissolved solids (TDS) were investigated in water samples collected from five different affected areas along with control. The EC of water is an indicator of salinity and hazard gives the total salt concentration in water (Brady and Well 2002). But all these EC values of water were within the permissible limit (Table 1). As per USEPA and DoE recommendation, water of control area has DO value within the permissible limit. In contrast, the DO values of five different affected areas were below the limit. Hazaribagh tannery area was the most vulnerable in respect to DO value (Table 1).

Table 1. Comparative analysis of physical and chemical parameters of water samples collected from control and different industrial effluent affected areas.

\begin{tabular}{llllll}
\hline Control/affected areas & Sample ID & $\mathrm{pH}$ & $\mathrm{EC}(\mu \mathrm{S} / \mathrm{cm})$ & $\mathrm{DO}(\mathrm{mg} / \mathrm{l})$ & $\mathrm{TDS}(\mathrm{mg} / \mathrm{l})$ \\
\hline Control & WCTR & 7.15 & 371 & 6.40 & 187.80 \\
Gazipur Garments & WGAZ & 7.34 & 1438 & 4.10 & 719.00 \\
ACME Lab. & WACME & 7.07 & 765 & 3.04 & 381.00 \\
Monno Ceramics & WMONNO & 7.09 & 353 & 5.63 & 174.02 \\
Savar Pesticides & WPSTD & 6.54 & 495 & 4.23 & 246.00 \\
Hazaribagh Tannery & WHAZ & 7.40 & 1230 & 0.88 & 624.00 \\
*Permissible limit & - & $6.50-8.50$ & $700-3000$ & 6 and above & $500-1500$ \\
\hline
\end{tabular}

*Source: Guide to the environmental conservation at 1995 and rules 1997.

Arsenic, cadmium, chromium, nickel, lead, iron, copper and zinc were investigated as trace metals in water samples collected from 5 different affected areas. The amount of chromium, nickel, copper and lead were below detection limit (BDL) and the amount of zinc and iron were within the permissible limit. On the other hand, arsenic and cadmium exceeded the permissible limit, according to DoE (Table 2) in water samples collected from all affected areas. Hazaribagh tannery was found as the most vulnerable area in respect to arsenic and chromium.

Arsenic, cadmium, chromium, nickel, zinc, copper, iron and lead were observed as heavy metals in soil samples collected from five different affected areas. It was found that except control, arsenic and chromium exceeded the permissible limit in each of the affected areas. According to 
Oellen (1997), the uptake of Cr was higher from coarse textured soil than from fine textured soil. Whereas cadmium, nickel and lead were present within the permissible limit (Table 3). Highest amount arsenic was found in the soil sample collected from Pesticide area (Table 3).

The amount of 5 heavy metals, namely arsenic, cadmium, chromium, nickel, iron, copper, ainc and lead were tested in Colocasia esculenta collected from five different effluent affected areas. Except lead rest of the heavy metals exceeded the permissible limit of which the amount of arsenic and cadmium were the highest (Table 4). Highest amount of arsenic and cadmium were found in the plant sample collected from Monno Ceramic area. This may be due to the fact that the metals were in a more labile state than those in the other soil samples (Cox and Hutchinson 1979, Farago and O'Connell 1983, Hogan and Wottom 1984). It was observed that the leaf portion accumulated more heavy metal than root (Table 4).

The amount of arsenic, cadmium, chromium, nickel, iron, copper, zinc and lead were observed in Ipomoea aquatica collected from five different industrial effluents affected areas. According to Kashem and Singh (1999), lead was found below detection level (BDL) in the control and samples collected from Acme Laboratory, Monno Ceramic and Pesticide areas. Although a little amount of lead was found in Gazipur textile and Hazaribagh tannery areas, remained within the permissible limit (Table 5). Maximum amount of arsenic and cadmium were found in the plant samples collected from ACME laboratory and Monno Ceramic areas. The leaf portions of these samples consumed more heavy metals than roots (Table 5).

From the above results it was evident that the physical and chemical properties such as: $\mathrm{pH}$, EC, TDS were within the safe limit in all the affected areas along with control. However, the amount of DO was below the permissible limit in all water samples except control (Table 1). The lowest amount of DO was found in the water sample of Hazaribagh tannery area. The amount of DO indicated the quality of the water helpful for survival of the aquatic organisms (Ahmed et al. 2000). The present results revealed that the water quality in the affected areas below the ambient/survival level and therefore, becomes a threat to the aquatic organisms. Moniruzzaman et al. (2009) reported that the DO of Hazaribagh affected area collected at different times of year ranged from $2.20-6.62 \mathrm{mg} / \mathrm{l}$. The present results showed that the DO value of Hazaribagh was $0.88 \mathrm{mg} / \mathrm{l}$ (Table 1) which was much lower than the earlier report. This result indicated that the DO is gradually decreasing in Hazaribagh area and thus, becoming a threat to aquatic organisms of this area.

Among the 8 heavy metals considered in this work, arsenic and cadmium surpassed the tolerable limit in the water sample of all affected areas. It was maximum in the water sample collected from Hazaribagh area (Table 2). The previous studies has been ensure that the atmospheric precipitation is very much responsible for metal contamination in surface water (Wong et al. 2003, Wu et al. 2008, Pandey et al. 2009).

Arsenic and chromium have crossed the permissible limit in the soil samples collected from 5 different areas. As per Imamul Huq et al. 2003 recommendation, all the soil samples collected from five different affected areas would have been contaminated primarily with cellulosic organic waste, with the metals bound to these organic materials rendering them less mobile for plant uptake. The amount of these elements were highest in Hazaribagh area (Table 3). In both the plant species, though the amounts of iron, copper and zinc were a bit above the acceptable limit, not much hazardous. Except lead, the other trace metals crossed the permissible limit (Tables 4-5). arsenic and cadmium were maximum in both the plant samples. The plant collected from Monno ceramic and Acme Laboratory areas had the highest amount of arsenic and cadmium indicating maximum discharging of arsenic and cadmium from these industries. It was found that the edible 

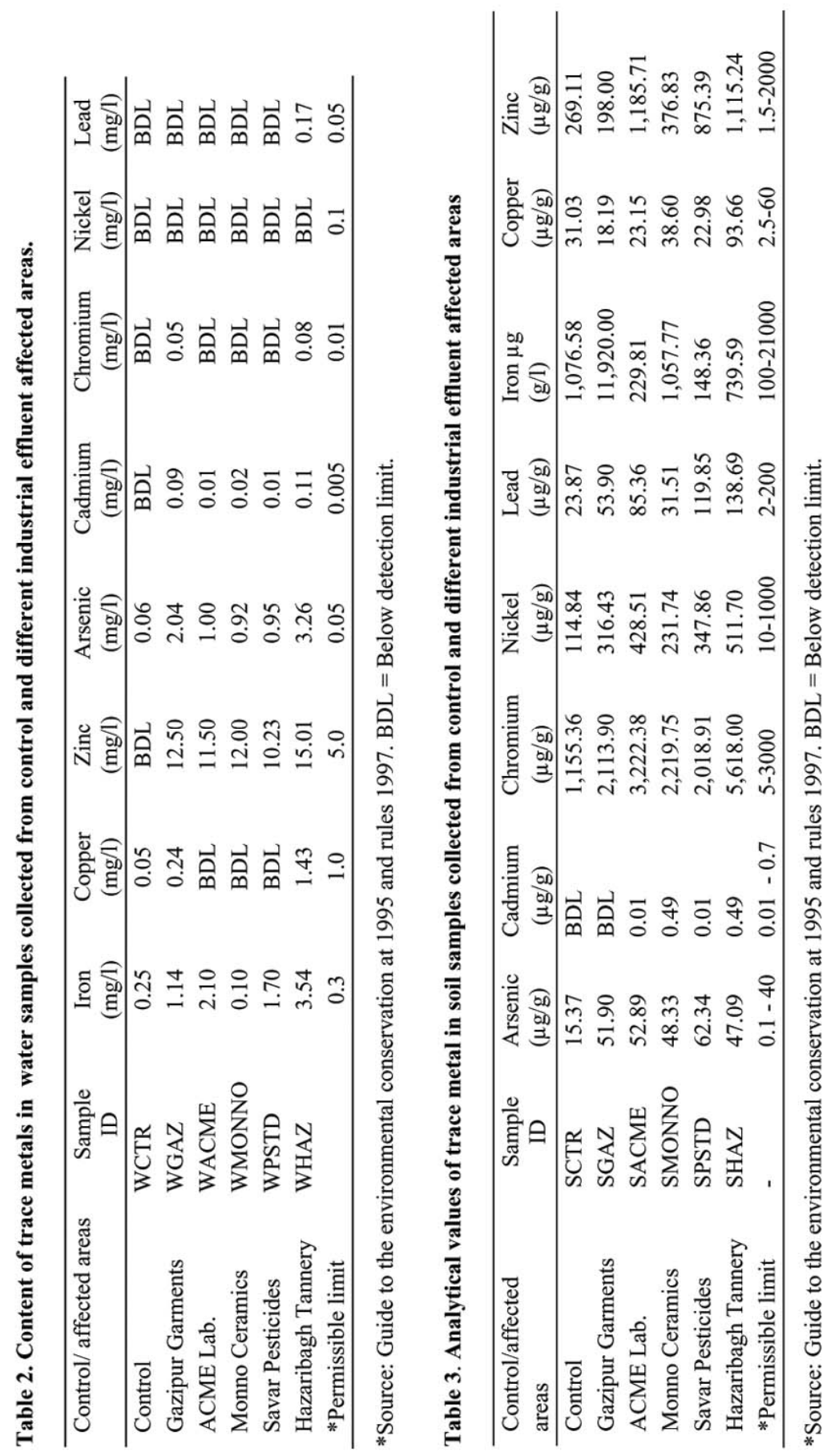


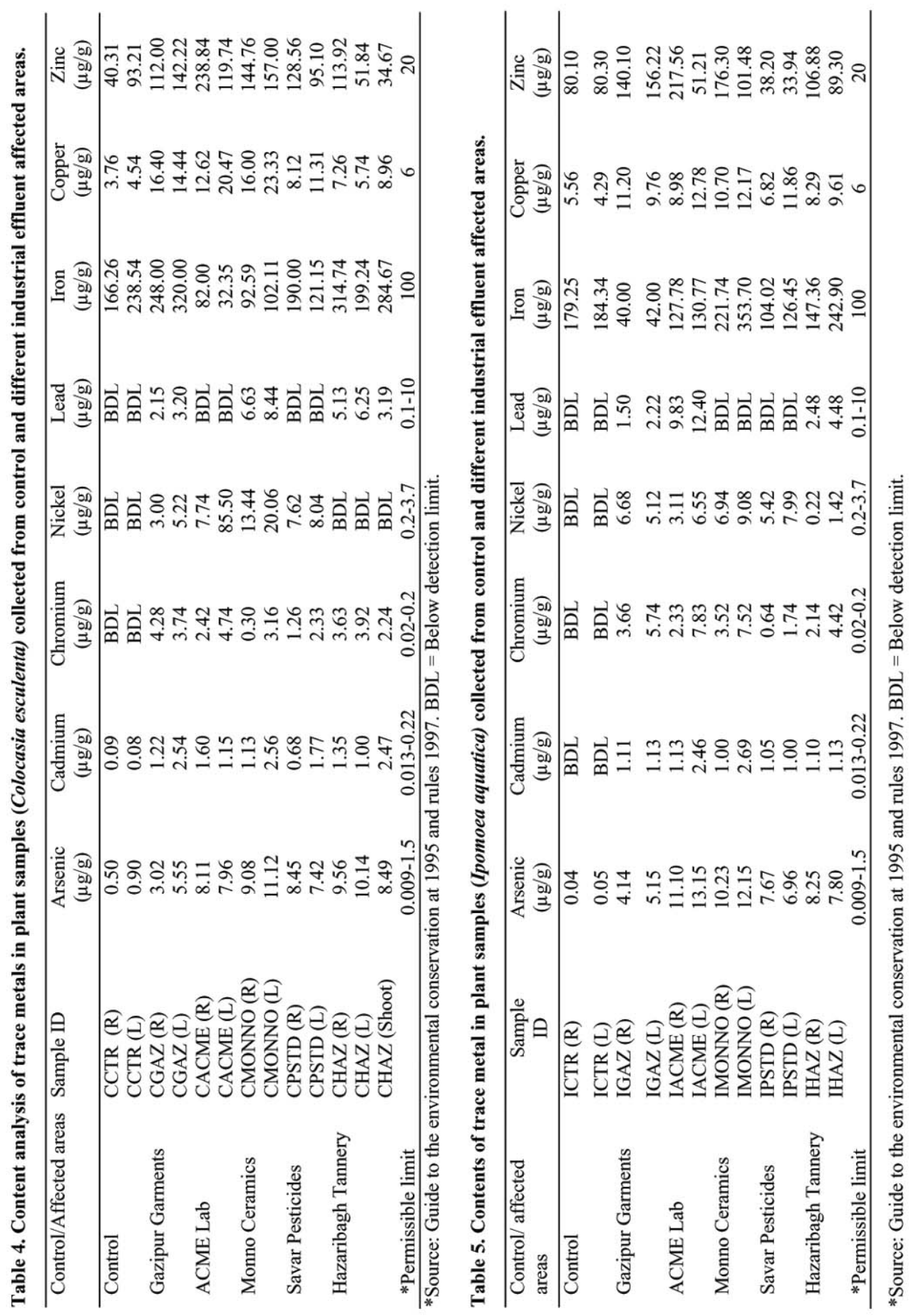


part had more cadmium and arsenic than roots (Tables 4 - 5), revealing quick uptaking of those heavy metals. From this study, it is clear that these heavy metals are entering into the human body through the edible parts of these plants.

\section{Acknowledgement}

The first author $(\mathrm{KKN})$ is grateful to the Ministry of Science and Information \& Communication Technology for offering Bangabondhu Ph.D. fellowship. Sincere thanks are due to all the members of Soil and Environmental Laboratory, BCSIR, Dhaka for their technical support.

\section{References}

Ahmed AU and Reazuddin 2000. Industrial pollution of water systems in Bangladesh, University press ltd., Dhaka, Bangladesh, 175-178.

Brady NC and Well RR 2002. The Nature and Properties of Soils. $12^{\text {th }}$ ed. Pearson Education, Inc. New Delhi, India. pp. 261-269.

Chan YK, Wong CK, Hsieh DPH, Lau TK and Wong PK 2003. Application of a toxicity identification evaluation for a sample of effluent discharged from a dyeing factory in Hong Kong. Environ. Tox. 18: 312-316.

Chhatwal GR, Mehra MC, Staka M, Katyal M and Nagahiru T 1989. Encyclopedia of environmental pollution and its control. Anmol publications, New Delhi, 6204.

Cox RM and Hutchinson TC 1979. Metal co-tolerances in the grass Deschampsia cespitosa. Nature 279: 231233.

DoE (Department of Environment) 1997. Bangladesh Gazette, No. DA-1. Dept. Environ. Ministry of Forest 1324-1327.

Farago ME and O’Connell JT 1983. Soil and plant concentrations of cadmium and zinc in the vicinity of a smelter. Miner. Environ. 5: 71-78.

Grover IS and Kaur S 1999. Genotoxicity of wastewater samples from sewage and industrial effluent detected by the Allium root anaphase aberration and micronucleus assays. Mutat. Res. 426: 183 - 188.

Hogan GD and Wottom DL 1984. Pollutant distribution effects in forests adjacent to smelters. J.Environ. Qual. 13: 377-382.

Huq ISM, Anisur R, Sultana N and Naidu R 2003. Extent and severity of arsenic contamination in soils of Bangladesh in Feroze MA, Ashraf MA and Jafar A (ed.) Fate of arsenic in the environment. Preprints of BUET-UNU international symposium, Dhaka. pp. 69-84.

Huq ISM and Alam MD 2005. A handbook on analysis of soil, plant and water. BACER-DU, Univ. Dhaka, Bangladesh 22: 246.

Huq ISM, Islam MS, Joarder JC and Khan TH 2006. Retention of arsenic, lead and cadmium in soil and their subsequent uptake by plants. Bangladesh J. Agric Environ. 2 (1): 61-68.

Huq ISM, Islam NM and Dus M 2000. Effect of automobile exhausts on nutritional status of soil and plant. Bangladesh J. Soil Sci. 26: 103-111.

Huq ISM, Shigenao K, Kashem AM and Singh RB 2008. Cadmium phytoextraction efficiency of Arum (Colocasia antiquorum), Radish (Raphanus sativus L.) and water spinach (Ipomoea aquatica) grown in hydrophonics. Water Air Soil pollut. 192: 273-279.

Islam MM, Mahmud K, Faruk O and Billah MS 2011. Textile dyeing industries in Bangladesh for sustainable development. Intl. J. Environ. Sci. Develop. 2(6): 428-436.

Joardar JC, Rashid MH and Huq ISM 2005. Adsorption of lead (Pb) by soil and their clay fraction. J. Asiat. Soc. Bangladesh Sci. 31: 63-74.

Kashem MA and Singh BR 1999. Heavy metal contamination of soil and vegetation in the vicinity of industries in Bangladesh. Water Air Soil Pollut. 115: 347-361. 
Lah B, Gorjane G, Nekrep FV and Marinsek-Logar R 2004. Comet assay of wastewater genotoxicity using yeast cells. Bull. Environ. Contam. Tox. 72: 607-616.

Lenore SC, Greenberg CAE and Eaton AD 1998. Standard methods for the examination of water and waste waters (20th Edition), Amer. Publ. Health Assoc., Washington DC.

Meybeck M and Helmer R 1996. Introduction: In: D. Chapman (Ed.) water quality assessments. A guide to the use of biota, sediments and water in environmental monitoring (2nd edition), Chapman and Hall, London.

Moniruzzaman M, Elahi SF and Jahangir MAA 2009. Study on temporal variation of Physical and chemical parameters of Buriganga river water through GIS (Geographical Information System) Technology. Bangladesh J. Sci. Ind. Res. 44(3): 327-334.

Odeigah C and Osanyinpeju 1995. Genotoxic effects of two industrial effluents and ethylmethane sulfonite in Clarias lazera. Food Chem. Tox. 33: 501-505.

Oellen H 1997. Uptake of six heavy metals by Oat as influenced by soil type and addition of $\mathrm{Cd}, \mathrm{Pb}, \mathrm{Zn}$ and Cu. Plant and Soil. 88: 57-69.

Pandey J, Shubhashish K and Pandey R 2009. Metal contamination of Ganga River (India) as influenced by atmospheric deposition. Bull. Environ. Contam. Toxicol. 83(2): 204-209.

Rahman A, Ali M A and Chowdhury F 2001. People’s report on Bangladesh environment, the University press limited pp. 153-159.

Smolders R, Bervoets L and Blust R 2004. In situ and laboratory bioassays to evaluate the impact of effluent discharges on receiving aquatic ecosystems. Environ. Pollut. 132(2): 231-243.

USEPA US Environmental protection Agency 1979. Methods for chemical analysis of water and wastes. Cincinnati: EPA-600/4-79-020.

Wong CSC, Li XD, Zhang G, Qi SH and Peng XZ 2003. Atmospheric deposition of heavy metals in the Pearl River Delta, China. Atmos. Environ. 37(6): 767-776.

Wu YF, Liu CQ and Tu CL 2008. Atmospheric deposition of metals in TSP of guiyang, PR China. Bull. Environ. Contam. Toxicol. 80(5): 465-468.

(Manuscript received on 27 November, 2014; revised on 10 April, 2015) 